GLOBAL JOURNAL OF GEOLOGICAL SCIENCES VOL. 18, 2020: 23-33

COPYRIGHT@ BACHUDO SCIENCE CO. LTD PRINTED IN NIGERIA ISSN 1596-6798

www.globaljournalseries.com, Email: info@globaljournalseries.com

\title{
PALEO-ENVIRONMENTAL DEDUCTION FROM PEBBLE MORPHOMETRY AND TEXTURAL STUDIES OF SANDSTONE DEPOSITS OF ISUOCHI AND ENVIRONS, ANAMBRA BASIN, SOUTH EASTERN NIGERIA.
}

EZIKE, EJIOFOR C., OKONKWO, HENRY I. AND IYI, EMMANUEL C.

(Received 18 December 2015; Revision Accepted 24 July 2019)

\begin{abstract}
Textural analysis and pebble morphomentric were carried out on the sandstone deposits of Isuochi area in Anambra Basin, in an attempt to reconstruct the paleoenvironment of deposition. Field observation shows that the sandstone samples, collected from various locations were analyzed for sieve analysis, while two hundred fresh quartz pebbles that are greater than $2.00 \mathrm{~mm}$ in diameter were collected for pebble morphomentric. Morphomentric parameters include; elongation ratio, flatness index, oblate index, and maximum projection sphericity were computed. Bivariate plots of Maximum Projection Sphericity against Oblate Prolate Index show that about $69 \%$ of the pebbles are of fluvial origin, while $31 \%$ is surf, bivariate plots of Flatness Index against Maximum Projection Sphericity show that about $57 \%$ is of fluvial origin, while $43 \%$ show surf; these imply that the associated pebbles are of fluvial origin. Bivariate plots of sandstone textural parameters such as skewness against standard deviation also suggest that the sediments are more of fluvial origin while multivariate parameter shows partly shallow marine environment.
\end{abstract}

KEYWORDS: Pebble Morphometry, Oblate-Prolate Index, Paleoenvironment.

\section{INTRODUCTION}

Sedimentation in the south eastern Nigeria started during the middle Albian which led to the deposition of the oldest sediment in the Southern Benue Trough mainly around Abakaliki; although some pyroclastics of Aptian Early Albian ages have been sparingly reported. Ojoh, (1990). Isuochi and environs, which is the study area is composed of sediments of Ezeaku Shale, Nkporo Shale, Mamu
Formation, Ajali Formation and Nsukka Formation. Major area covers includes: Umuokwu, Amuda, Ngodo, Lekwesi, Ugwueme and Lomara, with major outcrops being exposed along stream channels, quarries, Enugu-Port Harcourt express way and road cuts (figure 1). It lies between latitudes $05^{\circ} 56^{1} 0^{11} \mathrm{~N}$ and $06^{\circ} 01^{1} 00^{11} \mathrm{~N}$, and longitudes $07^{\circ} 22^{1} 0^{11} \mathrm{E}$ and $07^{\circ} 27^{1} 0^{11} \mathrm{E}$. Covers an areal extent of about $86 \mathrm{~km}^{2}$ approximately.

Ezike, Ejiofor C., Department of Geology and Mining, Enugu State University of Sciences and Technology, Enugu, Nigeria.

Okonkwo, Henry I., Department of Geology and Mining, Enugu State University of Sciences and Technology, Enugu, Nigeria.

lyi, Emmanuel C., Department of Geology and Mining, Enugu State University of Sciences and Technology, Enugu, Nigeria. 


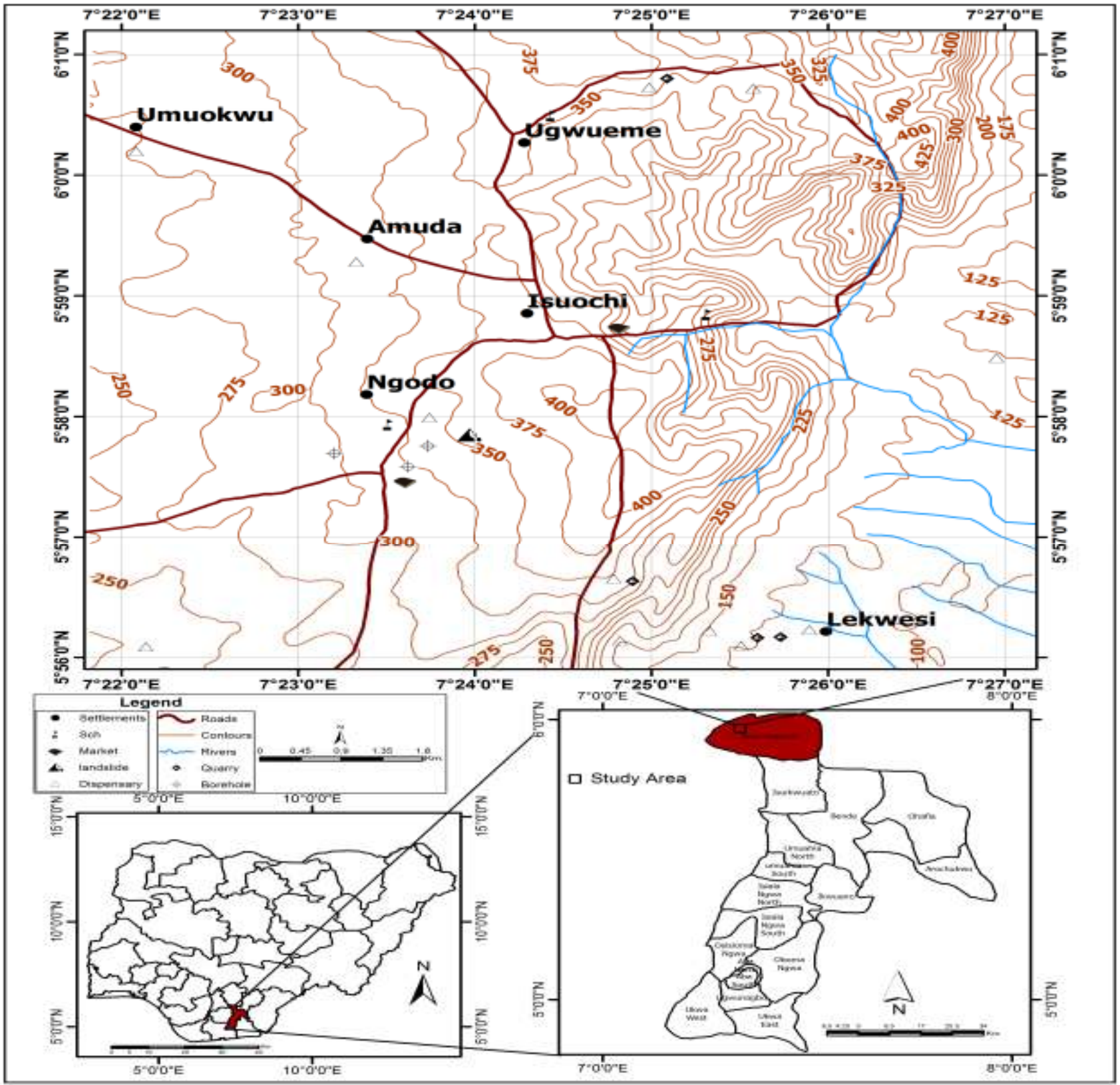

Figure 1: Location, Extent, and Accessibility map of the Study Area.

Simpson, (1955) and Reyment, (1965) noted that Asu River Group was deposited in a moderately deep water environment during the Albian, moderately folded, with NE-SW trending fold axes, abundant ammonites, forams, radiolarian, and pollens. The first marine regression in Benue Trough took place during the Early Cenomanian to Turonian; this led to the sediment deposition of Odukpani Formation. Burke, (1972), Reyment, (1965), and Murat, (1972) recorded that Eze-Aku Formation consist of dark grey to black shales, sandstone, subordinate limestone and siltstone which was deposited in a shallow marine environment, the sandstone deposits mark a period of regression, while the shale deposits indicate a period of transgression.. Offodile, (1976) noted that; there was an unconformity between the Turonian Eze-Aku Formation and the overlying Campanian-Maastrichtian Nkporo Shale. This explained the omission of the Awgu Formation in the syncline as a result of extensive erosion of older beds which accompanied the Santonian uplift. Sedimentation of the post-deformation in the Lower Benue Trough comprises of Anambra Basin Obaje, (2009). Agagu et al, (1985) and Reyment, (1965) were able to established stratigraphic sequence of the Anambra Basin which consists of Nkporo Shale, Mamu Formation, Ajali Formation, and Nsukka Formation in ascending order.

Tattam, (1944), Reyment, (1965, and Nwajide and Reijers, (1996) described Nkporo Shale as dark-light brown ferruginous shale, highly fissile shale and mudstone with thin beds of sandy shale. Oboh-Okuenobe et al, (2005), Simpson, (1955), and Dessauvagies, (1970) described Mamu Formation to composed of shale, sandy shale, mudstone, siltstone with coal seams at different horizon. Formed under low salinity condition of the sea. Kogbe, (1989), Murat, (1972) and Reyment, (1965) described Ajali 
Sandstone as poorly sorted sandstone, friable, white with iron-stained, with sparse cement of whitish clay. Tattam, (1944) first described Nsukka Formation as the "Upper Coal Measure" which marked the onset of another transgression in the Anambra Basin during the Paleocene (Obaje, 2013). The Nsukka Formation which overlies the Ajali Sandstone consists of medium to coarse grained sandstone, sandy shale with thin coal seams and carbonaceous dark shale (Obi, 2001, Murat, 1972 and Reyment, 1965).

The study presents detailed sedimentological pebble morphomentric and sandstone textural study of the area in order to depict the paleo environment of deposition.

\section{GEOLOGY AND STRATIGRAPHY OF THE STUDY AREA}

The geology of Isuochi is explicated in the geologic map (figure 2). Isuochi is underlain by six major lithological facies and five formations. These lithofacies are; the dark gray baked shale, light gray flaky shale, dark gray shale, dark mudstone, cross bedded sandstone and dark bluish mudstone while the formations are Ezeaku Shale, Enugu Shale, Mamu Formation, Ajali Formation and Nsukka Formation. The dark gray baked shale is fissile, light gray calcareous with dolerite sill intrusion overlies by carbonaceous mudstone. The light gray flaky shale is highly micaceous, calcareous and bears distributed limestone boulders within it. It appears dark coloured in some places. The dark gray shale is massive and highly homogeneous, fissile, poorly preserved wood fragment with thin bands of ironstone and claystone. The dark mudstone is carbonaceous, bluish shale with gastropod imprints and recies of wood fragments interbedded with sandstone and grayish siltstone. The sandstone within this facies is fine to medium grained with well exposed wave ripples and well preserved planolite and thalansinoid imprints. The cross bedded sandstone is friable, whitish to yellowish which consolidate towards the base. Averagely coarse and moderately to well sorted with clay at interval and ironstone capping it at the top. The sandstones are angular to sub-angular in shape with incidence of pebbles. Ripple marks, vertical symmetrical pellet wall of Ophiomorpha burrows, overturned beds, trough cross bedding, liesegang ring and wave rippled lamination are found within this facies. The dark bluish mudstone is carbonaceous with thin layers of coal and siltstone compacted together. The mudstone is reddish at weathered surface, interbedded with shale, sandy shale, sandstone and pyritic noodles.

The regional trend is NE-SW trend with an average dip of $8^{\circ}$. The afore mentioned facies are correlatable to the Ezeaku Shale, Enugu Shale, Mamu Formation, Ajali Formation and Nsukka Formation. 


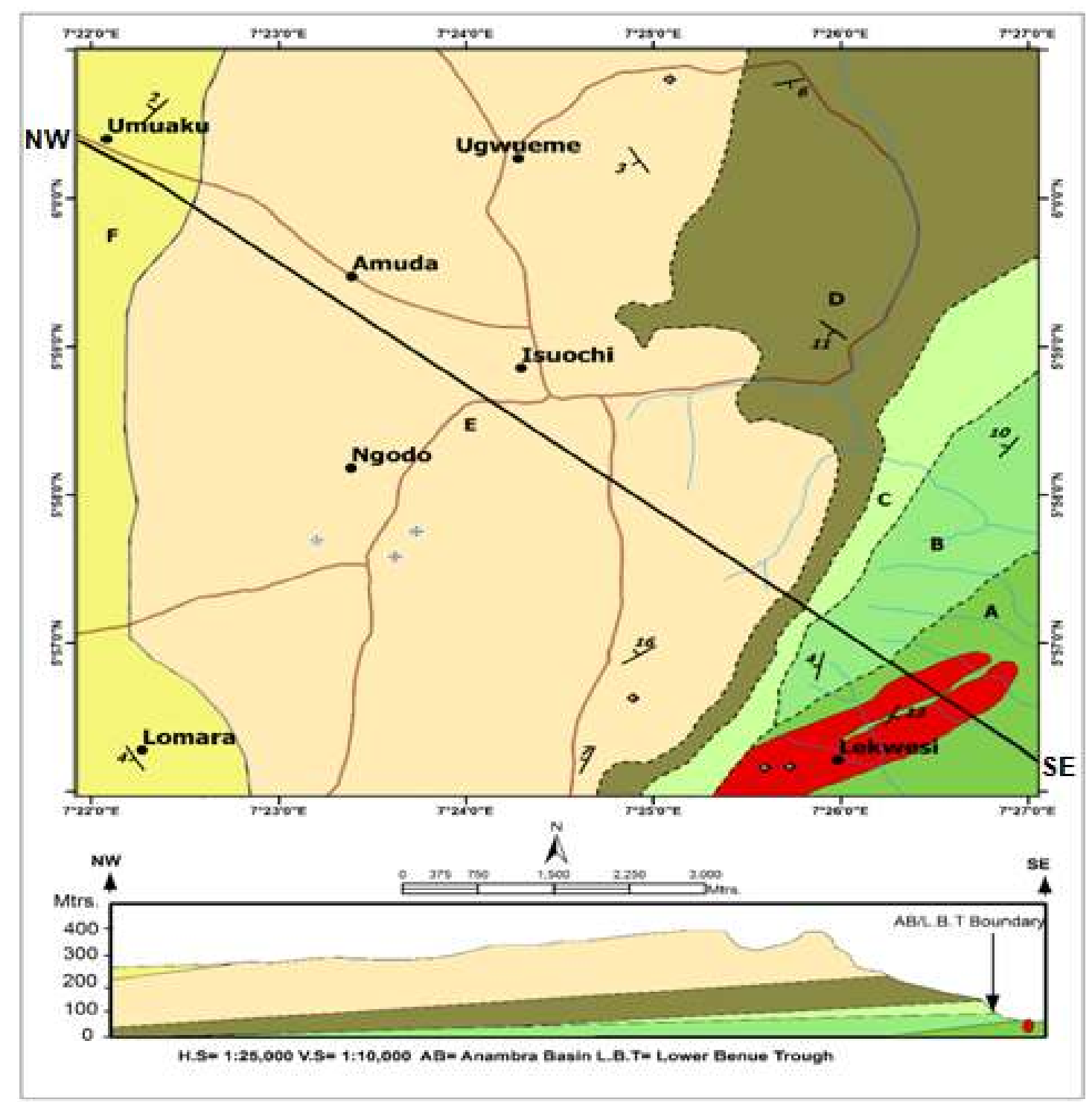

Litnost'at graphy of ihe study area

\begin{tabular}{|c|c|c|c|}
\hline Units & Lithologies & Format on & Aje \\
\hline$F$ & 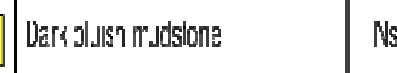 & 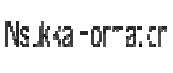 & \multirow{3}{*}{$v^{2}$} \\
\hline $\mathrm{E}$ - & Cross yedesc sandstene & A I Sarstene & \\
\hline $0 \square$ & 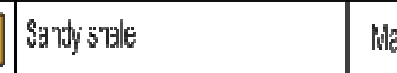 & Marr, Forment 01 & \\
\hline$c[$ & Dark CFa's shle & Errı, Snale & Camaan \\
\hline $\mid\left(10 \mathbb{N}^{2 / 2}\right.$ & Jnconto'm li & \multirow[t]{3}{*}{ 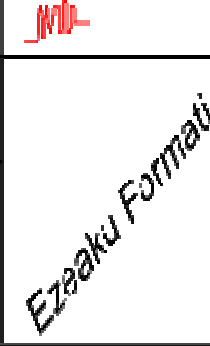 } & \multirow{3}{*}{$\left(v^{0}\right.$} \\
\hline$B$ & 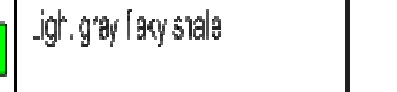 & & \\
\hline A & 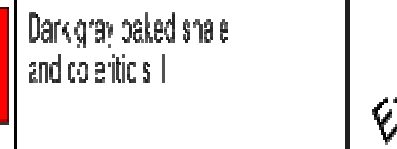 & & \\
\hline & $\begin{array}{l}{ }^{12} \text { Dip and Strike } \\
--- \text { Inferred Boundary } \\
- \text { Definite Boundary }\end{array}$ & 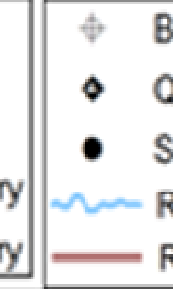 & \\
\hline
\end{tabular}

Figure 2: Geologic map of Isuochi 


\section{MATERIALS AND METHOD}

The desk study of the mapped area was conducted, followed by field mapping and laboratory analysis of the pebbles and sandstones. The desk studies involved the assemblage of all the available materials on the area in order to procure information on Isuochi and its environs. The field work involved the depletion of the lithofacies and collection of sandstones and pebble samples.

\section{PEBBLE MORPHOLOGY}

200 fresh unbroken pebbles were handpicked at discrete beds randomly within the study area. The samples were washed and numbered before taken to the laboratory. The analysis involves the measurement of the three mutually perpendicular diameters of pebbles using venier calliper. The three mutual perpendicular axes taken are: Long axes (L), Intermediate axes (I) and Short axes (S) of the pebbles according to (Zingg, 1935, Krumbein, 1941, Sneed and Folk, 1958 and Dobkins and Folks, 1970) the measurement obtained were recorded and used to determine parameters such as form (Zingg, 1935), mean, roundness and form indices (Dobkins, 1970 and Stratten, 1974), from which the bivariate plots are derived.

The average of "L" long, "I" intermediate, and "S" short axes for each samples were computed and applied in the computation of pebble morphomentric parameter are as follows:-
Flatness Index (FI): (S/L)* 100

Elongation ratios (ER): $\mathrm{I} / \mathrm{L}$ * 100

Maximum Projection Sphericity (

Lutig, 1962, and Sames, 1966)

(Lutig, 1962, and Sames, 1966)
$(\mathrm{L}-\mathrm{I}) /(\mathrm{L}-\mathrm{S})-0.5$

(Dobkins and Folk, 1970)

\section{$S / L$}

\section{Univariate pebble morphology parameters and} their indications Form

This describes the relationship between the long, intermediate and short axes. It involves using the comparison of the ratio of the intermediate axis to the long axis $(I / L)$ and the ratio of the short axis to the intermediate axis $(\mathrm{S} / \mathrm{I})$ in order to determine the shape classes which the pebbles as proposed by Zingg (1935) defined four shape classes, namely oblate, equiaxial, prolate and bladed based on these ratios (table 1).

Table 1: Shape classes according to (Zingg, 1935)

\begin{tabular}{|l|l|l|}
\hline $\mathbf{I} / \mathbf{L}$ & $\mathbf{S} / \mathbf{I}$ & Shape class \\
\hline$>0.67$ & $<0.67$ & Oblate \\
\hline$>0.67$ & $>0.67$ & Equiaxial \\
\hline$<0.67$ & $<0.67$ & Bladed \\
\hline$<0.67$ & $>0.67$ & Prolate \\
\hline
\end{tabular}

\section{SIEVE ANAYSIS}

Four sandstone samples were collected from various locations, samples were disaggregated in the laboratory with a rubber padded pestle as suggested by PettiJohn, (1975) $50 \mathrm{gm}$ of each disaggregated sample was measured using a weighing balance as test portions for sieve analysis. The test portions were sieved with a Ro- tag shaker for 15 minutes using a set of sieves with mesh size 0.5 phi apart. Cumulative curves of the grain size distribution were plotted from the sieve result. The univariate, and bivariate parameters were computed based on Folks and Ward (1957), Miola and Weiser (1977), and Sahu (1964). (Table 2).

Table2: Statistical parameter, their formula and verbal terminology (Folk and Ward (1957)

\begin{tabular}{|c|c|c|c|c|c|}
\hline Mean Size & Sorting & Ske & iness & Kurtos & \\
\hline$M_{Z}=\frac{\phi_{16}+\phi_{50}+\phi_{84}}{3}$ & $\sigma_{\mathrm{I}}=\frac{\phi_{84}-\phi_{1}}{4}$ & $+\frac{\phi_{95}-\phi_{5}}{6.6}$ & $\begin{array}{l}\frac{\phi_{16}+\phi_{84}-2}{2\left(\phi_{84}-\phi_{1}\right.} \\
\frac{\phi_{5}+\phi_{95}-2}{2\left(\phi_{95}-\phi_{5}\right.}\end{array}$ & $\mathrm{K}_{\mathrm{G}}=$ & $\frac{\phi_{95}-\phi_{5}}{4\left(\phi_{75}-\phi_{25}\right)}$ \\
\hline Sorting $\left(\sigma_{I}\right)$ & & Skewness $\left(\mathrm{Sk}_{\mathrm{I}}\right)$ & & Kurtosis $\left(\mathrm{K}_{\mathrm{G}}\right)$ & \\
\hline Very well sorted & $<0.35$ & Very finely & ${ }^{+} 0.3$ to $^{+} 1.0$ & Very platykortic & $<0.67$ \\
\hline Well sorted & $0.35-0.50$ & skewed & ${ }^{+} 0.1$ to ${ }^{+} 0.3$ & Platykortic & $0.67-0.90$ \\
\hline Moderately well sorted & $0.50-0.70$ & Finely skewed & ${ }^{+} 0.1$ to -0.1 & Mesokortic & $0.90-1.11$ \\
\hline Moderately sorted & $0.70-1.00$ & Symmetrical & 0.1 to 0.3 & Leptokurtic & $1.11-1.50$ \\
\hline Poorly sorted & $1.00-2.00$ & Coarsely skewed & 0.3 to -1.0 & Very leptokurtic & $1.50-3.00$ \\
\hline Very poorly sorted & $2.00-4.00$ & Very coarsely & & Extremely & $<3.00$ \\
\hline Extremely poorly sorted & $>4.00$ & skewed & & leptokurtic & \\
\hline
\end{tabular}




\section{RESULT AND DISCUSSION}

\section{Pebble morphometry}

The pebble morphometry results obtained from the analysis are tabulated in table 3 to 4 and figure 3 . The results show that $33.333 \%$ of the pebbles are equiaxial, $33.33 \%$ are oblate, $16 \%$ are prolate, while $10 \%$ are bladed. Based on mean roundness, $29 \%$ of the pebbles are very angular, $25 \%$ are angular, while $31 \%$ are subangular and $13 \%$ are sub-rounded pebbles. Only $2 \%$ of the pebbles are rounded. Roundness of pebbles tend to increase from rivers to beaches, hence with the low percentage of round pebbles (sub-rounded and rounded), it is likely that the pebbles have been affected by fluvial processes. The high amount of equiaxial pebbles compared to the oblate, prolate and bladed pebbles $(38 \%)$ shows a greater tendency towards sphericity, which decreases from rivers to beaches. This means that the pebbles have been affected by fluvial process (Dobkins and Folk, 1970).

From the limits for form indices given by Dobkins and Folk (1970) and Stratten (1974), it is observed that the larger percentages of the pebbles fall within the limits of form indices for fluvial processes. The values of the average OPI, MPS and FI also fall within the limits of form indices for fluvial processes. These indicate that the environment of deposition of the pebbles was fluvial dominated.

The bivariate plot of MPS vs. OPI (Figure 4) shows $73 \%$ of the plots in the fluvial portion of the graph; $1 \%$ in the beach portion of the graph, while $26 \%$ plots in the lower portion non-diagnostic portion of the graph. The high percentage plots in the fluvial field of the graph indicates fluvial dominated environment.

\section{Grain Sizes of sandstone}

The result of the grain size analysis for sandstone shown in table 5. It can be observed that mean sizes of the sandstone are predominated by coarse sand, ranges from $0.608-0.856$. The standard deviation (sorting) shows that the sandstone are moderately sorted, ranging from 0.818 0.963 . The skewness values indicate symmetrical $(-0.005-$ 0.093) expect for unit 2 that is fine-skewed (0.293). The coefficient kurtosis ranges from platykortic-mesokorticleptokortic (0.769-1.197).Bivariate plots of mean size against standard deviation (figure 5), and skewness against Standard deviation (figure6) shows that sandstone are predominated with fluvial processes.

Table 3: Univariate pebble morphology parameters and their interpretation

\begin{tabular}{|c|c|c|c|c|c|c|c|c|}
\hline \multirow{5}{*}{ Sample } & \multirow{2}{*}{$\begin{array}{l}\begin{array}{l}\text { Univariate } \\
\text { parameters }\end{array} \\
\text { Form }\end{array}$} & \multicolumn{6}{|c|}{ Amount of pebbles (\%) } & \multirow{2}{*}{$\begin{array}{l}\text { Interpretation } \\
\text { Fluvial }\end{array}$} \\
\hline & & $\begin{array}{l}\text { Equiaxial } \\
33.333 \%\end{array}$ & $\begin{array}{l}\text { Oblate } \\
36.66 \%\end{array}$ & $\begin{array}{l}\text { Prolate } \\
20 \%\end{array}$ & $\begin{array}{l}\text { Bladed } \\
10 \%\end{array}$ & & & \\
\hline & $\begin{array}{l}\text { Mean } \\
\text { roundness }\end{array}$ & $\begin{array}{l}\text { Very } \\
\text { angular } \\
29 \%\end{array}$ & $\begin{array}{l}\text { Angular } \\
25 \%\end{array}$ & $\begin{array}{l}\text { Sub- } \\
\text { angular } \\
31 \%\end{array}$ & $\begin{array}{l}\text { Sub- } \\
\text { round } \\
13 \%\end{array}$ & $\begin{array}{l}\text { Rounded } \\
20 \%\end{array}$ & & Fluvial \\
\hline & $\begin{array}{l}\text { From } \\
\text { indices }\end{array}$ & OPI & & MPS & & $\mathrm{FI}$ & & \\
\hline & & $\begin{array}{l}(>1.5) \\
100 \%\end{array}$ & $\begin{array}{l}(<1.5) \\
0 \%\end{array}$ & $\begin{array}{l}(>0.65) \\
74.1 \%\end{array}$ & $\begin{array}{l}(<0.65) \\
25.9 \%\end{array}$ & $\begin{array}{l}(>45) \\
100 \%\end{array}$ & $\begin{array}{l}(<45) \\
0 \%\end{array}$ & Fluvial \\
\hline
\end{tabular}

Table 4: Percentage Proportion of pebble Shape

\begin{tabular}{|l|l|l|}
\hline \hline \multicolumn{3}{|c|}{} \\
\hline \hline Sneed \& Folk classes & Count & Percent \\
\hline \hline Compact & 4 & 2.00 \\
Compact-Platy & 7 & 3.50 \\
Compact-Bladed & 32 & 16.00 \\
Compact-Elongate & 25 & 12.50 \\
Platy & 19 & 9.50 \\
Bladed & 68 & 34.00 \\
Elongate & 27 & 13.50 \\
Very-Platy & 1 & 0.50 \\
Very-Bladed & 15 & 7.50 \\
Very-Elongate & 2 & 1.00 \\
\hline
\end{tabular}




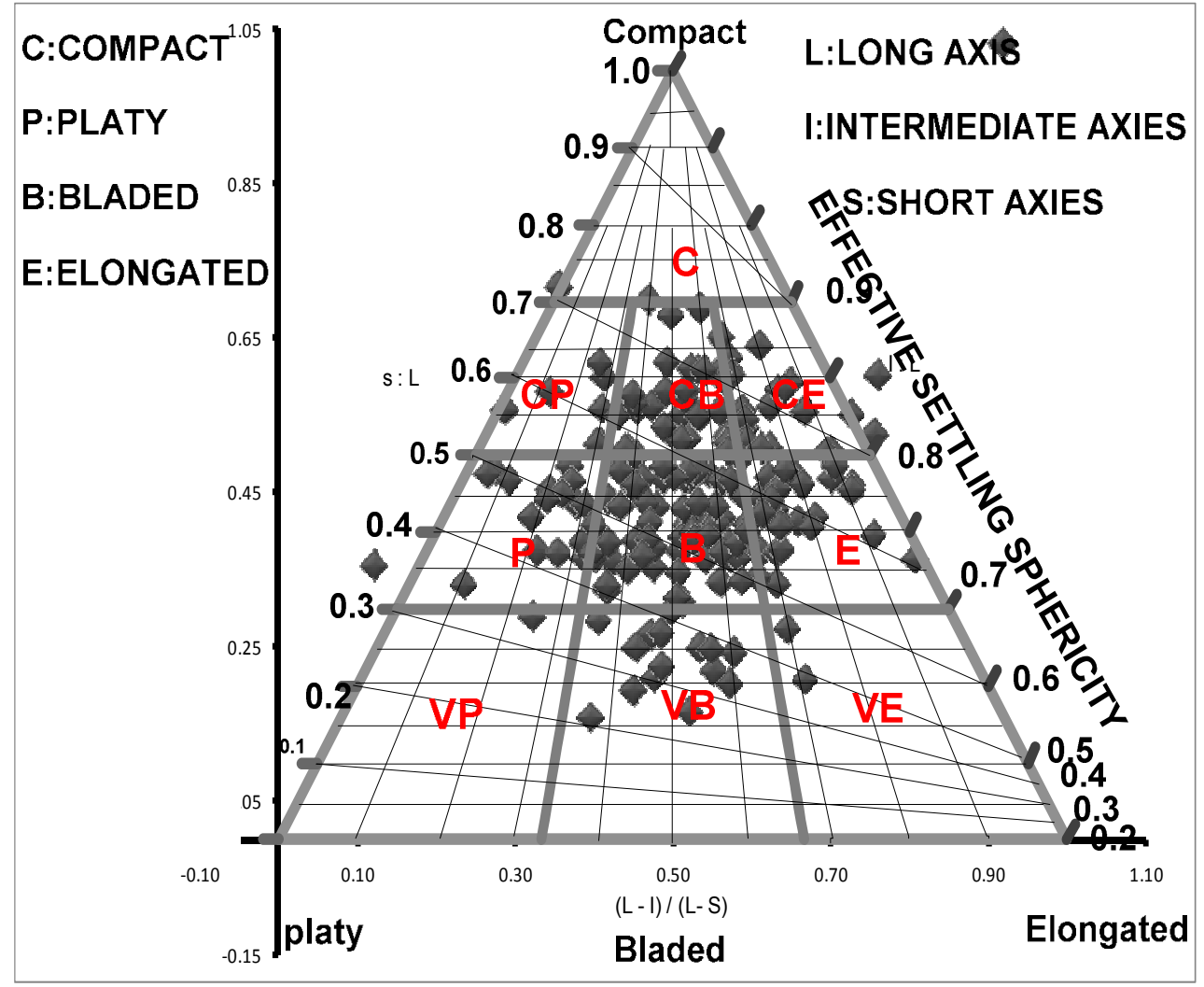

Figure 3: Form shape diagram (after Sneed and Folks, 1958)
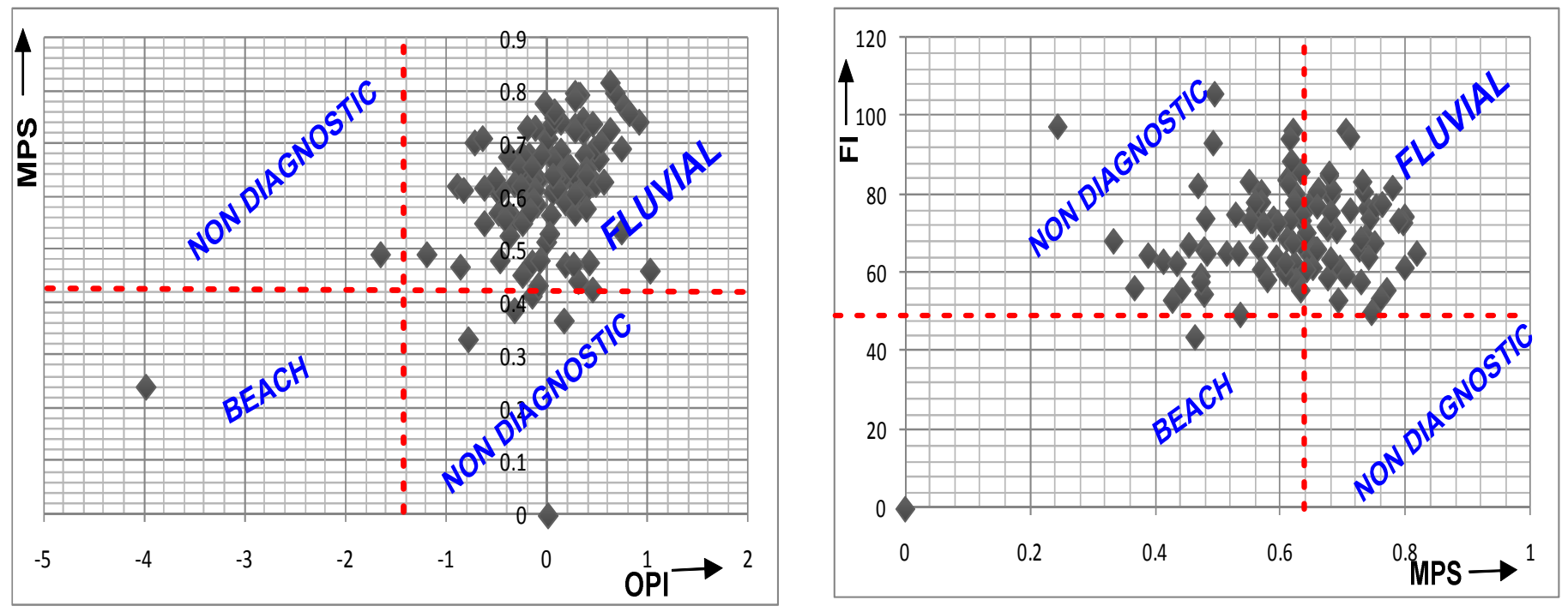

Figure 4: Bivariate plot of MPS vs. OPI. 
EZIKE, EJIOFOR C., OKONKWO, HENRY I. AND IYI, EMMANUEL C.

Table 5: Statistical parameters with their descriptive terminologies for the analyzed samples (after Folk and Ward, 1957)

\begin{tabular}{|c|c|c|c|c|c|}
\hline & $\begin{array}{l}\text { SAMPLE } \\
\text { IDENTITY: }\end{array}$ & Unit 1 & Unit 2 & Unit 3 & Unit 4 \\
\hline \multirow{4}{*}{$\begin{array}{l}\text { Folk and } \\
\text { ward method } \\
\text { (O): }\end{array}$} & Mean $\left(M_{z}\right)$ : & 0.608 & 0.606 & 0.856 & 0.786 \\
\hline & Sorting $\left(\mathrm{O}_{1}\right)$ : & 0.818 & 0.996 & 0.953 & 0.947 \\
\hline & $\begin{array}{l}\text { Skewness } \\
\left(\mathrm{SK}_{\mathrm{I}}\right) \text { : }\end{array}$ & -0.005 & 0.293 & 0.093 & -0.080 \\
\hline & Kurtosis $\left(\mathbf{k}_{\mathrm{G}}\right)$ : & 1.034 & 1.197 & 0.988 & 0.769 \\
\hline \multirow{4}{*}{$\begin{array}{l}\text { Folk and } \\
\text { ward method } \\
\text { (Description) }\end{array}$} & Mean: & Coarse sand & Coarse sand & Coarse sand & Coarse sand \\
\hline & Sorting: & $\begin{array}{l}\text { Moderately } \\
\text { sorted }\end{array}$ & $\begin{array}{l}\text { Moderately } \\
\text { sorted }\end{array}$ & $\begin{array}{l}\text { Moderately } \\
\text { sorted }\end{array}$ & $\begin{array}{l}\text { Moderately } \\
\text { sorted }\end{array}$ \\
\hline & Skewness: & $\begin{array}{l}\text { Symmetrical } \\
\text { skewed }\end{array}$ & Fine- skewed & $\begin{array}{l}\text { Symmetrical } \\
\text { skewed }\end{array}$ & $\begin{array}{l}\text { Symmetrical } \\
\text { skewed }\end{array}$ \\
\hline & Kurtosis: & Mesokortic & Leptokortic & Mesokortic & Platykortic \\
\hline
\end{tabular}

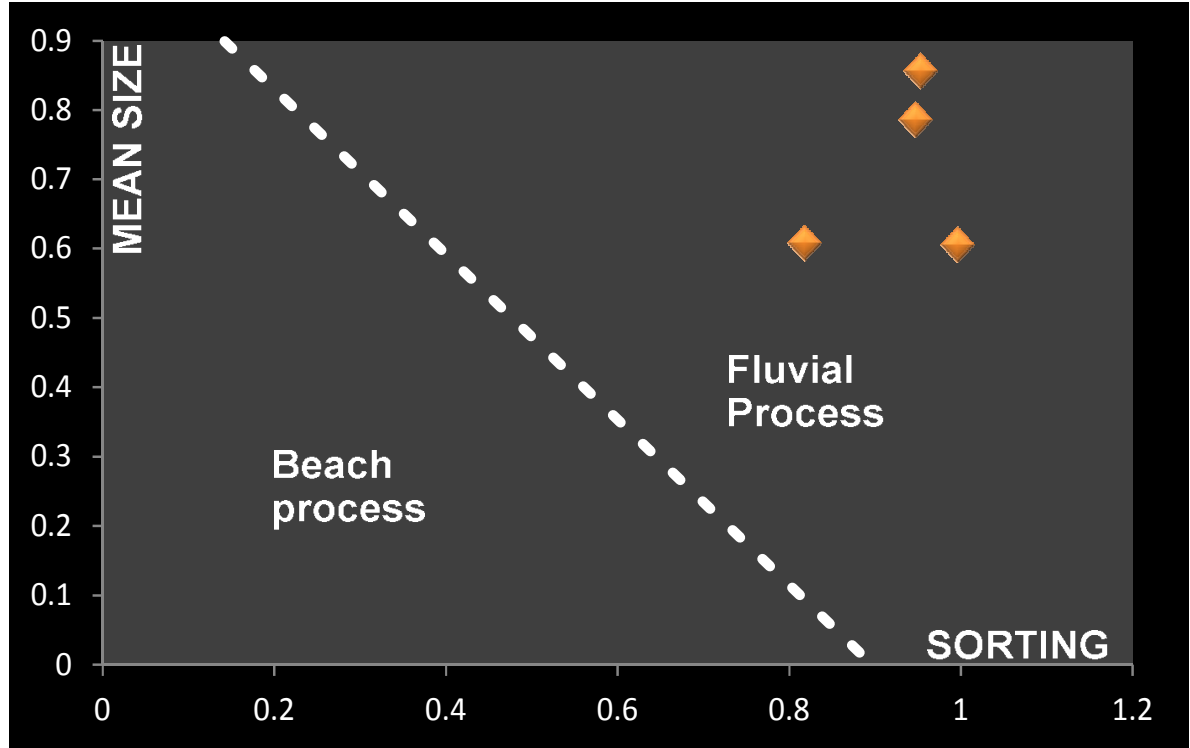

Figure 5: Plot of mean size against standard deviation

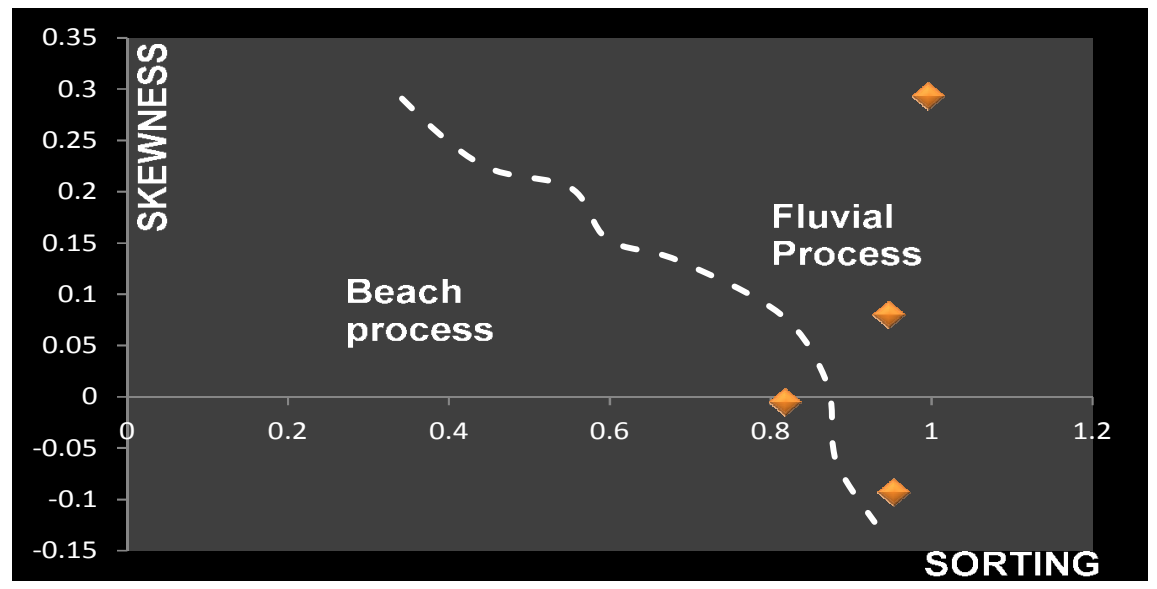

Figure 6: Plot of skewness against standard deviation 


\section{SUMMARY AND CONCLUSION}

On the basis of pebble form indices, it is evident that the pebbles were shaped in fluvial environment.

Results from sieve analysis show that the sediments is predominated by coarse size sands, moderately sorted, symmetrical skewness and ranges from platykorticmesokortic-leptokortic kurtosis. These data were used for bivariate plots of skewness against sorting/standard deviation and mean size against standard deviation. All the graphs depict fluvial depositional environment for the sediments.

\section{ACKNOWLEDGEMENTS}

"Neither fire nor wind, birth nor death can erase our good deeds" (Lord Buddha). The sacrifices of some individuals that helped me realize this work will always remain green in my mind. Whatever I do here in the form of appreciation is only but a token.

I am grateful to God Almighty for his grace, favour, blessing, and love to finish this work. Within the course of the field mapping, it became all the more obvious to me that "no man is an island"; that human beings of all God's creation, are special species, who depend on each other for success and survival. I lack words to express my deep gratitude to Rev. Fr. Anthony Ukaegbu, Mr. Okonkwo, Henry I. Mr. R.A.N Nwatarali, Mrs. Amaka Nwonu, Prof. Barth Ekwueme, Rev. Fr. Joseph Inmpey and others for their special assistance, concerns, challenges, guidance and support which made it possible for this project work to be executed.

Finally, my special thanks equally go to my friends John Nsofor, Calister Onyia, Theophilus Kanu, Chinenye Omeje, Orji Valentine, Vincent Nwobodo, Chinenye Ozormgbechi, and others who helped in one way or other. Remain blessed.

\section{REFERENCES}

Agagu, O. K.., Fayose, E. A., and Petters, S. W., 1985. Stratigraphy and sedimentation in the Senonian Anambra Basin of Eastern Nigeria: Nig. Jour. Min. Geol, v. 22, p. 25-36.

Burke, K., 1972. Long shore drift, submarine canyons and submarine fans in Development of Niger Delta. American Association of Petroleum Geologists Bull. 56, p. 1975-1983.

Dessauvagies, T. F., Burke, K. C., and Whiteman, A. J., 1970. Geologic History of the Benue valley and Adjacent Areas, In: T. F. J. Dessauvagies and A. J. Whiteman, Eds, African Geology. Ibadan University Press, Ibadan, p. 187-205.

Dobkins, J. E., and Folk, R. L., 1970. Shape development on Tahati-Nui: Jour. Sed. Petrology, v. 40, p. 1167-1203.

Folk, R. L. and Ward, W. C., 1957. Brazon River Bar: a study of the significance of gram size parameters. Journal of Sedimentary Petrology, v. 27, No. 1, p. 3-26.
Kogbe, C. A., 1989. Palegeographic history of Nigeria from Albian times, $2^{\text {nd }}$ revised ed., in C. A. Kogbe, ed., Geology of Nigeria: Rock view Pub. Nig. Ltd., Jos. 263pp.

Krumbrien, W. C., and Monk, G. D., 1941. Permeability as a function of size parameters of unconsolidated sand: Pet. Technol, v.5, p.1-11.

Lutig, G., 1962. The shape of pebbles in the continental, fluviatile and marine facies. Int. Assoc. Sci. Hydrol. Publ., 59, p. 253-258.

Miola, R. J. and Wiese, D., 1977. Textural Parameters: an Evaluation. Jour. Sed. Petrology, v. 38, p. 45-53.

Murat, R. C., 1972. Stratigraphy and paleogeography of the Cretaceous and Lower Tertiary in Southern Nigeria, In T.F.J., Dessauvagies, and A.J. Whiteman, eds., African Geology: University of Ibadan Press, p. 251-268.

Nwajide, C. S. and Reijers, T. J. A., 1996. Geology of the Southern Anambra Basin. Selected Chapters on Geology, p. 131-139.

Obaje, N. G., 2009. The Benue Trough; in Geology and Mineral Resources of Nigeria, Lecture notes in Earth Sciences, p.120 - 145 .

Obaje, N. G., 2013. Updates on the geology and mineral resources of Nigeria. Onaivi printing and publishing Co. Ltd. Abuja-Nigeria, p.49-52.

Obi, G. C., 2001. The Geology of the Lower Benue Trough, University of Nigeria Nsukka.

Oboh-Okuenobe, E. F., Obi, G. C., and Jamarillo, A. C., 2005. Lithofacies, Palynofacies and Sequence Stratigraphy of Paleogene strata in Southeastern Nigeria: Journal of African Earth Sciences, v.41, p. 79-102.

Offodile, M. E., 1976. A Review of the Geology of the Cretaceous of the Benue Valley in: C. A, Kogbe, Eds., Geology of Nigeria, Elisabethen, Pub. Co., Lagos, p. 319-330.

Ojoh, K., 1990. Cretaceous Geodynamic evolution of the Southern Part of the Benue Trough (Nigeria) in the Equatorial Domain of the Southern Atlantic: Stratigraphy, Basin Analysis and Paleogeography. Bull. Centres Rech. Explor- Prod. Elf-Aquitaine, v. 14, p. 419-442.

PettiJohn, F. J., 1975. Sedimentary rocks, $3^{\text {rd }}$ ed.: Harper and Row, New York, 628pp.

Reyment, R. A., 1965. Aspects of the geology of Nigeria: the stratigraphy of the Cretaceous and Cenozoic Deposits. Ibadan University Press, p. 51-145. 
Sahu, K. B., 1964. Depositional Mechanism for Size Analysis of Clastic Sediments. Jour. Sed. Petrology, v. 34, p. 73-83.

Simpson, A., 1955. The Nigerian coalfield: the geology of parts of Onitsha, Owerri and Benue provinces Geo. Surv. of Nigeria Bull. No. 24, 85p.5pl.

Sames, C. W., 1966. Morphometric data of some recent pebble association and their application to ancient deposits. Journal of sedimentary petrology, 36, p.126-142.
Sneed, E. D., and Folk, R. L., 1958. Pebbles in the Lower Colorado River, Texas, a study in particle morphogenesis: Jour, Geol, v. 66, p. 114-150.

Stratten, T., 1974. Notes on the application of shape parameters to differentiate between beach and river deposits in southern Africa. Transactions Geological Society, South Africa, v. 77, p. 59-64.

Tattam, C. N., 1944. A review of Nigeria stratigraphy: Geo. Surv. of Nig, p. 27-46.

Zingg, T. H., 1935. Beitrage zur Schotteranalyse, Schweizer, Mineralogy, U, Petrog, Mitt, v. 15, p. 39-140. 

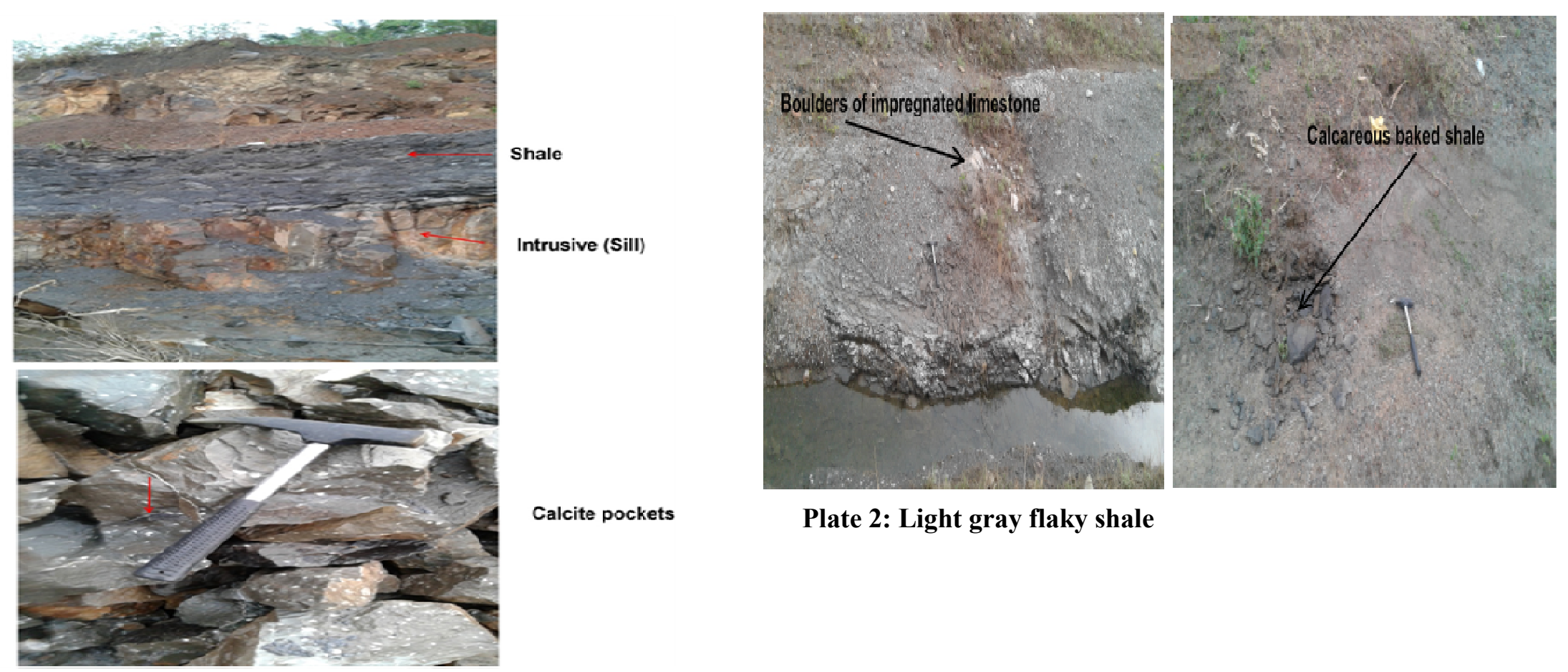

Plate 1: Dark gray baked shale and dolerite intrusion

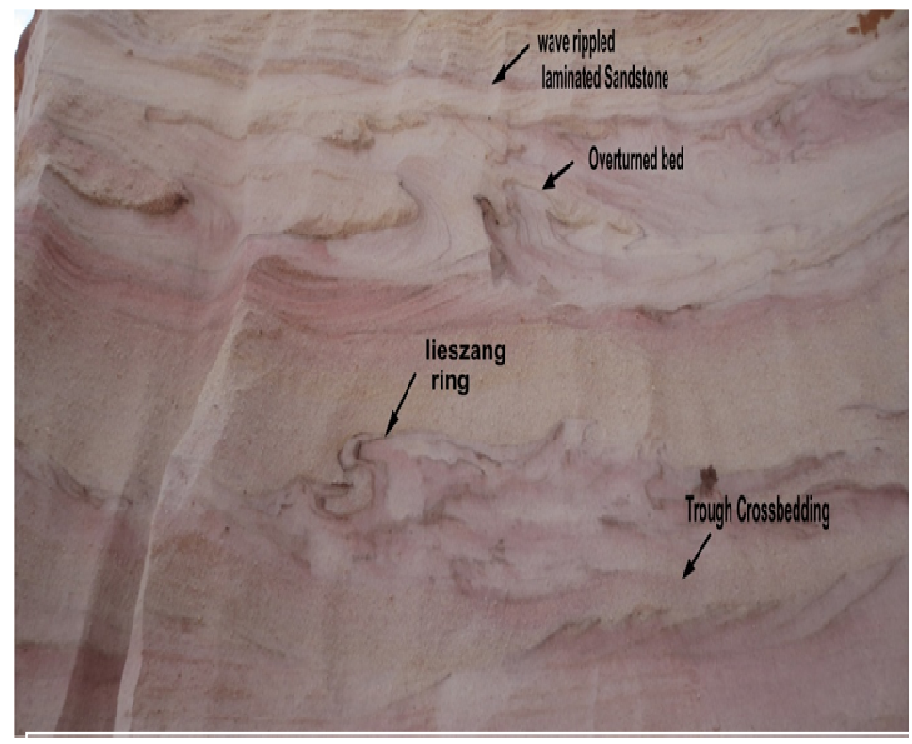

Plate 3: Cross bedded sandstone

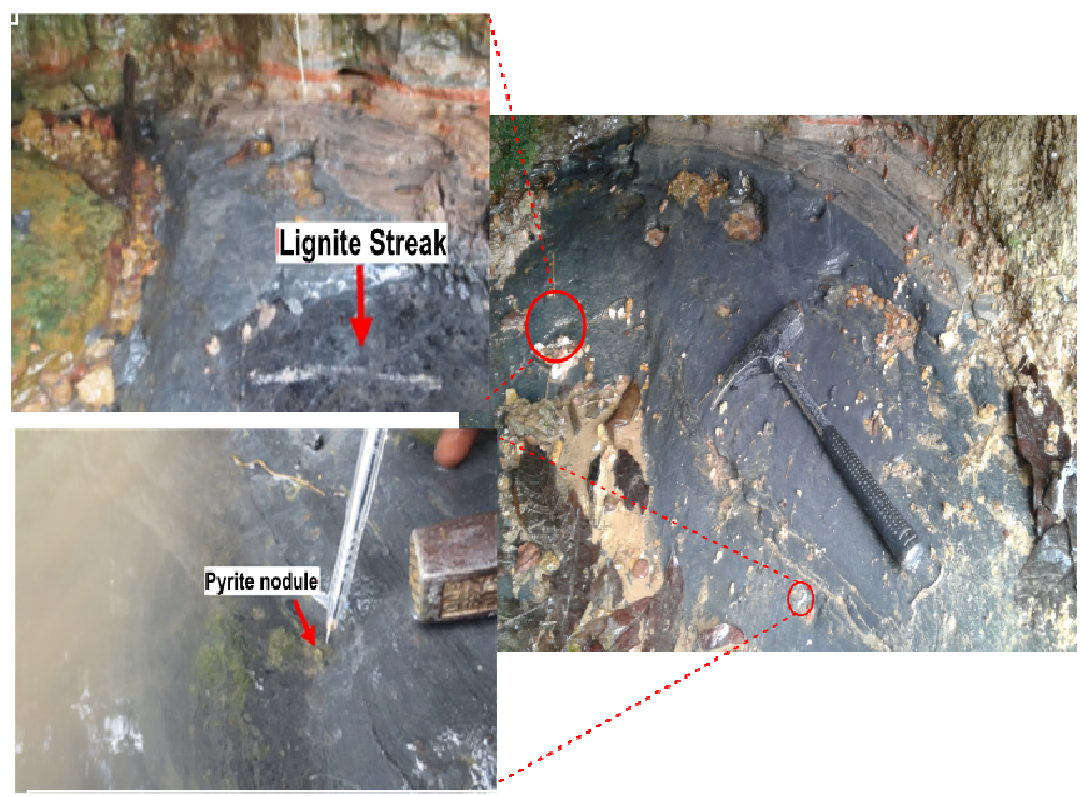

Plate 4: Dark bluish shale and mudstone 